\title{
Professional Competences of Jurisprudence Educators
}

\author{
Anzhela A. Husenko ${ }^{1}$, Iaroslav V. Petrunenko², Olha O. Kulinich ${ }^{3}$, Liudmila V. Tokar ${ }^{4}$ \& Vita V. Herashchenko \\ ${ }^{1}$ Department of Public Administration and International Economics, Mykolayiv National Agrarian University, \\ Mykolayiv, Ukraine \\ ${ }^{2}$ Department of Economic Law and Procedure, National University "Odesa Law Academy”, Odesa, Ukraine \\ ${ }^{3}$ Department of Intellectual Property Relations, Section of Educational Activities, the State Enterprise "Ukrainian \\ Intellectual Property Institute" (UKRPATENT), Kyiv, Ukraine \\ ${ }^{4}$ Department of Philosophy, National University “Odesa Law Academy”, Odesa, Ukraine \\ ${ }^{5}$ Department Pedagogical and Psycho logical Schools, National Pedagogical Dragomanov University, Kyiv, Ukraine \\ Correspondence: Anzhela A. Husenko, Mykolayiv National Agrarian University, 9 Georgy Gongadze str., Mykolayiv, \\ 54020, Ukraine.
}

Received: June 10, 2020

Accepted: August 3, 2020

Online Published: August 10, 2020

doi:10.5430/ijhe.v9n7p345

URL: https://doi.org/10.5430/ijhe.v9n7p345

\begin{abstract}
Nowadays, the profession of Jurisprudence educator is one of the most relevant and top requested among all specializations; however, in order to become a high-skilled Jurisprudence educator, one should possess significant professional qualities, including being professionally competent in the context of teaching. Taking into consideration the above mentioned, as well as based on the subject matter of the scientific article, the purpose of the study is to reveal the theoretical and practical features of the professional competences'formation and development of the Jurisprudence educators. Methods of analysis, synthesis, observation, description, comparison and generalization have been applied to reveal the purpose of the scientific research. It has been established that modern Jurisprudence teachers should possess the following professional competences: to be fluent in modern legislation and other legal norms; to rely on the features and qualities of leading scientists, working in this field; to be able to interconnect private and public interests and allocate responsibility to individual cases; to be well-versed in legislative practice and to act by law in unexpected situations; to encourage students to actively participate in the learning process, while avoiding delays in classes or even truancies; to expect knowledge from their studentsin a positive light; to enlist the respect and trust of students; to treat students positively and with respect, regardless of their religious, cultural, social or linguistic background; to cooperate with parents and other students' custodial persons; to think critically and professionally; to prepare for classesto a full extent, using modern innovative teaching methods to teach material in the classroom;to take an active part in activities organized by the tertiary educational institution, local community, etc.; to be engaged in professional development, constantly improve one's own competences. Based on the results of the conducted study of the theoretical and practical features of the professional competences' formation and development of Jurisprudence educators it has been established that these competences begin to form and develop even at the stage, when students (future Jurisprudence educators) study at the tertiary legal educational institutions.
\end{abstract}

Key words: professional competences, legal education, educator, tertiary educational institutions, jurisprudence

\section{Introduction}

Currently, competence is one of the key erudition qualities of a teacher of a tertiary educational institution. Studies prove that competence is the trait of an educator that indicates the appropriate level of knowledge, as well as the acquired skills and practical abilities that he / she possesses and properly directs to the learning process (Siri, Supartha, Sukaatmadja \& Rahyuda, 2020). "Teachers' competence in educational assessment is a key feature in teacher professionalism" (DeLuca, Schneider, Coombs, Pozas \& Rasooli, 2020).

Rapid technological changes have led to the revision of curricula in " 'law schools'...but also in a more generalised effort to improve "teaching the law" (Tsaoussi, 2020). "Law programs first moved from traditional content-focussed programs toward incorporating critique and legal skills". There is a dilemma in the development process of professional competences: professional skills require development, but soft skills are becoming increasingly important. Emotional and social intelligence are becoming increasingly important in professional activities, and 
teachers should obtain similar skills to transfer experience to students. "Legal pedagogy seems to focus disproportionately on the traditional model of the 'thinking lawyer', when it should equally promote the model of the 'feeling lawyer', helping students to sharpen soft skills such as empathy, integrity and problem-solving" (Tsaoussi, 2020). Recent investigations point up the fact that emotional work "has often been implicit or unrecognized in the role of legal academics" (Heath, Galloway, Skead, Steel \& Israel, 2017).

Herewith, it should be noted that among all specializations, currently, the profession of an educator of legal disciplines is one of the most relevant and top requested. However, in order to become a high-skilled Jurisprudence educator, one should possess significant professional qualities, including being professionally competent in the context of teaching.

Thus, based on the foregoing, as well as on the basis of the topic of scientific research, the subject matter of the scientific article is to study the peculiarities of the professional competences' formation of the educators of legal disciplines (Jurisprudence).

\section{Literature Review}

Taking into account the outlined subject matter of scientific research, the review of literary sources will be based on the context of the theoretical principles' disclosure of professional competences of Jurisprudence educators.

"Teacher competence and commitment have significantly positive effect on the performance of professional teachers... It is necessary to support the improvement of the competence and commitment of teachers" (Siri, Supartha, Sukaatmadja \& Rahyuda, 2020).

Professional competence should be formed while studying at the tertiary educational institution. Therefore, the knowledge, skills and abilities acquired at the tertiary educational institution have an impact on the development and the professional potential implementation of the future Jurisprudence educator, and this, in turn, will contribute to fulfilment of professional functions in the future of teaching legal disciplines. In addition, Gherashhenko (2018) notes that prospective educators should be fertile in the following competences, namely:

1) methodological competence;

2) communicative competence;

3) organizational competence;

4) analytical competence;

5) research competence;

6) psychological competence;

7) civic competence.

An important component of training Jurisprudence educators is communicative competence. The scholar has proven that Jurisprudence educators should possess a high level of communicative competence, as this is a key aspect of the quality of their professional activities (Gherashhenko, 2019).

The feature of professional competence of Jurisprudence educators is characterized as an integrative personality trait. Along with this, the individual should possess a number of professionally significant scientific and theoretical knowledge and practical skills and abilities to carry out pedagogical activities. In the course of the investigation conducted, the scientist identifies the following key types of competences that the Jurisprudence educator should possess, namely: 1) axiological competences; 2) general professional competences; 3) project competences; 4) communicative competences; 5) information and communication competences (Shestopaljuk, 2014).

The possessing competence means that an educator (a lecturer) should have the appropriate level of knowledge, skills and abilities that are necessary for teaching schoolchildren (students) the basics of law (Prokopchuk, 2017).

Training in special elective courses plays an important role in this the process.Scientists have also developed a model of professional competence's formation of applicants of legal education, the basic implementation principles of which are the following elements (Akhmejanova, Olzhabayev, Zhanara, Avikhan \& Sakenov, 2016), namely:

1) the professional competences' development of applicants of legal education is carriedout due to: a)studying modern legislation and other norms of law; b) the ability to interconnect private and public interests and to divide responsibility into individual cases; в) the ability to be well-versed in legislative practice and act by law in unexpected situations; 
2) organizational conditions professional competences' formation of applicants of legal education (i.e. the training quality level ofapplicants of legal education, the quality level of delivering material by educators, the level of innovation and technological methods of teaching academic disciplines;

3) criteria for assessing the professional competence of applicants of legal education;

4) levels of professional competence of applicants of legal education (low, intermediate and high);

5) features of optional courses (the presence of a number of disciplines, such as legal psychology, legal workshop, methods of organization of the lawyerin the educational process).

Currently a "great deal of attention has been paid to the nature of teaching and the qualities a good teacher ought to possess", however "there has been little emphasis on the specific characteristics and competencies that teacher educators should have" (Celik, 2011).

"Competency development focuses on constructing a framework for developing lawyers today. In doing so, "competences draw on the past, live in the now, and look to the future" (Mottershead \& Magliozzi, 2013).

The professional competence of future educators is formed during the training period, when the students' potential is revealed, knowledge is acquired and skills are developed to solve problems in accordance with unexpected situations (Muslimov \& Kadyrov, 2015).

In order to form students'motivation to learn, the educator, especially in the legal direction, should be professionally guided by his skills. In order to achieve a high level of students' learning effectiveness, the educator should timely deliver the task to students and assess them in due time, encourage students to actively participate in the learning process, while not being late for classes or truancies (Sparrow, 2018).

In turn, Gerst and Hess (2009) study the issues of the formation and development of professional values and skills that are acquired as a result of obtaining a tertiary legal education.

Modern law specialist should rely on the characteristics and qualities of leading scholars, working in this field. In particular, the Jurisprudence educatorin his professional activity has to (Schwartz, Hess \& Sparrow, 2013):

1) think critically and professionally;

2) expect knowledge from their students in a positive light;

3) enlist the respect and trust of students;

4) prepare for classes to a full extent, using modern innovative teaching methods to teach material in the classroom.

"Legal educators should strive to meet these standards in order to produce high quality research to help guide the future of legal education. Many legal education topics are ripe for qualitative research" (Hess, 2014). Herewith, the scientist emphasizes that currently important topics, influencing the formation and development of professional competences of the Jurisprudence educators are as follows: "1) students' learning of doctrine, skills, and professionalism in a course; 2) teachers'andstudents'experiencesinvariouscourseformats - face-to-face, online, blended; 3) mentorrelationships - facultyto faculty, faculty to student, student to student; 4) developing a rigorous externshipprogram; 5) students' development of professionalism through three years of law school; 6)faculty development programs - scholarship and teaching; 7) graduates' successes andstruggles in the first two years of practice" (Hess, 2014).

There are two basic areas of formation of educators' legal competence, namely: 1) the legal competence of the educator is formed in special pedagogical conditions with a tendency to the peculiarities of the educational process of tertiary education; 2) the legal competence of the educator is formed in the context of informational and orientation conditions, in which the legal consciousness and knowledge of the legal foundations of a citizen takes pride of place (Baklanova, 2016).

In recent decades, legal educators and academics have become increasingly aware that the set of skills known as "soft skills" is a necessary complement to the traditional hard skills imparted to law students. Law schools can strike a better balance between hard skills (learning about the law) and soft skills (learning about the social environment of the law and how to maximise performance in it, through better communication and forging strong interpersonal relationships with colleagues, clients, etc.). If the balance between these two modes of learning is not maintained, law school graduates are likely to underperform as lawyers, judges or legal counsellors in firms and corporations (Tsaoussi, 2020). Adoption of the National Qualifications Framework has strengthened the requirements for professional competences, in particular by identifying areas for competence development within EU (Chakroun, 
2019). More than 120 countries worldwide are reforming their qualifications systems and, in most cases, adopting outcomes based frameworks (Table 1).

Table 1. Overall conceptualisation and relationship of standards related to Competence standards and Professional standard

\begin{tabular}{|c|c|c|}
\hline & Competence standards & Professional standard \\
\hline Informs & $\begin{array}{l}\text { Establish standards for competence } \\
\text { required to perform specific tasks } \\
\text { in workplace. It also informs } \\
\text { competence- based training }\end{array}$ & Professional designations \\
\hline Guided by & Competence level descriptors/units & $\begin{array}{l}\text { Professional developmen } \\
\text { requirements, profiles }\end{array}$ \\
\hline Located within & $\begin{array}{l}\text { Competence } \\
\text { Frameworks/Occupational } \\
\text { classification }\end{array}$ & $\begin{array}{l}\text { Professional frameworks anc } \\
\text { pathways }\end{array}$ \\
\hline
\end{tabular}

Sourse: Chakroun (2019)

Professional standards are considered as important tools to develop teachers' professionalism. They may be generic or specific: generic standards being a broad set of descriptors that teachers can aspire to or hope to achieve, whereas specific standards are more explicit and can allow assessors to evaluate teachers' performance in relation to a set of descriptors. Professional standards can be defined by governments or through social dialogue (Fransson, Gallant \& Shanks, 2018).

CPD, professional standards, competence frameworks and qualifications for teachers will become even more important in the context of the "future of work" and "future of learning", a scenario which anticipates that individuals will need to change jobs and acquire new skills on a regular basis (International Labour Office, 2019; United Nations, 2019).

Competence defines the "ability to apply learning outcomes adequately in a defined context (education, training, work or professional development)" (Cedefop, 2014). Hence, a competence is an achieved learning outcome.

\section{Data and Methods}

Methods of analysis, synthesis, observation, description, comparison and generalization have been used and applied to reveal the purpose of scientific investigation, which centers aroundanalyzing, studying and assessingthe theoretical and practical features of the professional competences' formation and development of Jurisprudence educators.

The information provided by Stanford University (2014), Columbia Law School (2020), UC Berkeley School of Law (n.d.), Harvard Law School (n.d.), the University of Chicago (2020), Yale Law School (n.d), the University of Toronto Faculty of Law (n.d) and European Commission (2013) constitutes the methodological basis of the study.

The information has been collected on the websites of the universities and contained data on the curriculum, career development of the teacher, competences approved by the university. The method of content analysis is used to study information about the curriculum and competences of Jurisprudence educators. An additional source of data was the Times Higher Education rating, 2020: Ranking of the top 20 universities in the world according the level of teaching legal disciplines in 2020; Ranking of the top 20 universities in the world according the level of teaching legal disciplines in 2018.

A rating was used to select universities that offer research papers in the field of law top 20 universities in the world according the level of teaching legal disciplines in 2020, in particular World University Rankings 2020 by subject: law.

The ranking was contained in the database The World University Rankings (2019), which together with Elsevier forms a list of the most effective universities in the level of teaching law on a number of indicators (Table 2).

Table 2. World University Rankings 2020 by subject: law 


\begin{tabular}{|c|c|c|c|c|c|}
\hline Rank & $\begin{array}{c}\text { Name } \\
\text { Country/Region }\end{array}$ & $\begin{array}{l}\text { No. of FTE } \\
\text { Students }\end{array}$ & $\begin{array}{c}\text { No. of students } \\
\text { per staff }\end{array}$ & $\begin{array}{l}\text { International } \\
\text { Students }\end{array}$ & $\begin{array}{c}\text { Female:Male } \\
\text { Ratio }\end{array}$ \\
\hline 1 & $\begin{array}{l}\text { Stanford University } \\
\text { United States }\end{array}$ & 16,135 & 7.3 & $23 \%$ & $43: 57$ \\
\hline 2 & $\begin{array}{l}\text { University of Cambridge } \\
\text { United Kingdom }\end{array}$ & 18,978 & 10.9 & $37 \%$ & $47: 53$ \\
\hline 3 & $\begin{array}{l}\text { Yale University } \\
\text { United States }\end{array}$ & 12,402 & 5.4 & $20 \%$ & $50: 50$ \\
\hline 4 & $\begin{array}{l}\text { University of Oxford } \\
\text { United Kingdom }\end{array}$ & 20,664 & 11.2 & $41 \%$ & $46: 54$ \\
\hline 5 & $\begin{array}{l}\text { University of Chicago } \\
\text { United States }\end{array}$ & 13,833 & 5.7 & $28 \%$ & $46: 54$ \\
\hline 6 & $\begin{array}{l}\text { University of California, } \\
\text { Berkeley } \\
\text { United States }\end{array}$ & 41,081 & 13.7 & $17 \%$ & $50: 50$ \\
\hline 7 & $\begin{array}{l}\text { Duke University } \\
\text { United States }\end{array}$ & 15,309 & 4.3 & $19 \%$ & $49: 51$ \\
\hline 8 & $\begin{array}{l}\text { London School of Economics } \\
\text { and Political Science } \\
\text { United Kingdom }\end{array}$ & 10,570 & 12.1 & $71 \%$ & $53: 47$ \\
\hline 9 & $\begin{array}{l}\text { New York University } \\
\text { United States }\end{array}$ & 44,466 & 8.9 & $33 \%$ & $57: 43$ \\
\hline 10 & $\begin{array}{l}\text { University of Toronto } \\
\text { Canada }\end{array}$ & 73,370 & 20.1 & $21 \%$ & $59: 41$ \\
\hline 11 & $\begin{array}{l}\text { University of California, Los } \\
\text { Angeles } \\
\text { United States }\end{array}$ & 41,066 & 9.4 & $17 \%$ & $54: 46$ \\
\hline
\end{tabular}

Sourse: The World University Rankings (2019)

After selecting the universities, their requirements for the competencies of teachers were analyzed. They are set out in the normative internal documents.

\section{Research Results}

In the course of revealing the practical features of the professional competences' formation and development of Jurisprudence educators, we should focus on the results of the study presented by the global trade union - Education International.

Thus, the study "Quality Educators: An International Study of Teacher Competences and Standards", conducted by the global trade union organization, Education International (2011), states that educators, in the context of their professional activities should possessthe following professional competences:

1) to treat students positively and with respect, regardless of their religious, cultural, social or linguistic background;

2) to be guided by the law and ethical principlesin the educational process;

3) tobe polite to students in order to encourage them to learn;

4) to cooperate with parents and other students' custodial persons;

5) to cooperate with other educators of the tertiary educational institution;

6) to take an active part in activities organized by the tertiary educational institution, local community, etc.; 
7) to be engaged in professional development, constantly improve one's own competences.

Taking into considerationthe above mentioned professional competences, which should be possessed by the educator in the process of carrying out his professional activities, fit clearly to a number of professional competences of the Jurisprudence educator. Therefore, it should be noted that a modern Jurisprudence educator should possess bothvarious competences, defined according to the profile of his professional activity, and those, listed above by the global trade union organization, Education International (2011), in the study "Quality Educators: An International Study of Teacher Competences and Standards".

It is worth noting that the level of prestige of the tertiary educational institution, where educators carry out their professional activities, depends on the level of professional competence of Jurisprudence educators.

For instance, Stanford University (2014) (the United States), which is one of the most prestigious universities in the world, has special programs, involving students in continuing research activities at this tertiary institution. Taking this into consideration, students, as future Jurisprudence educators, acquire the appropriate knowledge and practical skills. In the course of such a process, students as future Jurisprudence educators form professional qualities that should be applied and used by them in the context of further teaching (pedagogical) activities.

In order to teach Jurisprudence at the University of Chicago (2020) (the United States), you need to be a high-skilled specialist. Herewith, a potential educator, who wants to teach at this university, should successfully go through one of these ways:

1) to graduate with honors from law school, to constantly provide their services regarding the review of the law, while holding a high editorial position;

2) to complete studies with a high level of knowledge, possess practical skills and work experience in paperwork;

3) to have additional academic experience, which is obtained by a potential educator during carrying out research activities after graduating from the law school (The University of Chicago, 2020).

There are a number of requirements for a potential educator of Yale Law School (n.d) (the United States), including: 1) academic literacy; 2) the availability of the necessary knowledge; 3) practical experience; 4) potential teaching ability, including the ability to hold classroom discussions or seminars; 5) occupying a position in legal journals or holding a position in the legal service (optional).

Every potential educator, who wants to teach at Harvard Law School (the United States) should overcome quite a complex process of receiving permission to train students. Thus, a potential educator, preparing for a teaching career, should participate in programs that are specifically designed by Harvard Law School in order to attract only worthy educators to the learning process. Moreover, the potential educator should conduct research in the field of law. It should be noted that about $11 \%$ of all Jurisprudence educators, who teach at American law schools, are graduates of Harvard Law School (n.d.).

Prospective educators, who want to create a successful teaching career at Columbia Law School (the United States), should participate in programs specifically designed by Columbia Law School (2020). Thus, the program "The Careers in Law Teaching" is intended to provide graduates and students who are interested in further academic activities, assistance from professors in the development of an individual academic research program and preparation for building an educator's career in the future.

An educator's career at the University of Toronto, Faculty of Law (Canada) begins with obtaining the bachelor's degree. In addition, in order to continue studies at this tertiary institution, candidates should pass the standardized LSAC test, the results of which are assessed by an independent non-profit organization (University of Toronto Faculty of Law, n.d).

At the same time, in order to obtain permission to teach at UC Berkeley School of Law (the United States), it is necessary to publish articles in legal journals, to have support from other educators concerning conducting training activities. However, in contrast, it is also necessary to participate in the annual recruitment conference organized by the Association of American Law Schools (AALS).

It should also be noted that there is legislation in the Netherlands that requires educators to meet the requirements of competence; herewith, tertiary educational institutions should promote the professional development of educators. At the same time, educators are expected to maintain their competences at the appropriate level due to continuous training, the time for which should be approximately 10\% of the total working time (European Commission, 2013). 
Therefore, based on the above assumptions, it is necessary to present a number of leading institutions of tertiary education, one of the educational areas of which is the legal direction, because, in our opinion, the Jurisprudence educators with a high level of professional competence work in such tertiary educationalinstitutions.

Thus, according to the annual ranking of tertiary educational institutions, World University Rankings, presented by the Times Higher Education magazine, in 2020, the best universities in the world, occupying the first five positions among 190 universities in the world, are as follows: Stanford University (2014) (the United States), the University of Cambridge (the United Kingdom), Yale University (the United States), the University of Oxford (theUnited Kingdom) and the University of Chicago (2020) (the United States) (Table 3).

Table 3. Ranking of the top 20 universities in the world according the level of teaching legal disciplines in 2020

\begin{tabular}{|c|c|c|c|c|c|}
\hline Country & Rank & University & $\begin{array}{l}\text { Number } \\
\text { of FTE } \\
\text { students }\end{array}$ & $\begin{array}{c}\text { Number of } \\
\text { students } \\
\text { per staff }\end{array}$ & $\begin{array}{l}\text { International } \\
\text { students, \% }\end{array}$ \\
\hline The United States & 1 & Stanford University & 16135 & 7,3 & 23 \\
\hline The United Kingdom & 2 & The University of Cambridge & 18975 & 10,9 & 37 \\
\hline The United States & 3 & Yale University & 12402 & 5,4 & 20 \\
\hline The United Kingdom & 4 & The University of Oxford & 20664 & 11,2 & 41 \\
\hline The United States & 5 & The University of Chicago & 13833 & 5,7 & 28 \\
\hline The United States & 6 & $\begin{array}{l}\text { The University of California, } \\
\text { Berkeley }\end{array}$ & 41081 & 13,7 & 17 \\
\hline The United States & 6 & Duke University & 15309 & 4,3 & 19 \\
\hline The United Kingdom & 8 & $\begin{array}{l}\text { London School of Economics and } \\
\text { Political Science }\end{array}$ & 10570 & 12,1 & 71 \\
\hline The United States & 9 & New York University & 44466 & 8,9 & 33 \\
\hline Canada & 10 & The University of Toronto & 73370 & 20,1 & 21 \\
\hline The United States & 11 & $\begin{array}{l}\text { The University of California, Los } \\
\text { Angeles }\end{array}$ & 41066 & 9,4 & 17 \\
\hline Australia & 12 & The University of Melbourne & 47385 & 26,3 & 46 \\
\hline The United States & 13 & Harvard University & 20823 & 9,2 & 24 \\
\hline The United Kingdom & 14 & UCL & 32665 & 10,6 & 52 \\
\hline Singapore & 15 & National University of Singapore & 30869 & 17,9 & 28 \\
\hline The United States & 16 & Columbia University & 26586 & 5,8 & 37 \\
\hline Hong Kong & 17 & The University of Hong Kong & 18260 & 18,2 & 44 \\
\hline The United Kingdom & 18 & The University of Edinburgh & 29433 & 12,8 & 41 \\
\hline Australia & 18 & UNSW Sydney & 44336 & 35,7 & 41 \\
\hline Canada & 20 & McGill University & 31294 & 13,0 & 29 \\
\hline
\end{tabular}

Source: The World University Rankings (2019)

Among the universities mentioned above, the greatest number of intramural students (20664) is studying at the University of Oxford in 2020, despite the fact that this university takes the fourth place in the ranking.This university also has the largest number of students per lecturer (over 11 people) among the 4 other universities in the top 5 World University Rankings.For the matter of international students, the University of Oxford has the largest number of such students $(41 \%)$.

In addition, the leading universities of such countries, as: the United States, the United Kingdom, Canada, Australia, Singapore, and Hong Kong are included in the top 20 universities, presented in Table 3 and defined by World University Rankings.

Assessing the positions of universities in World University Rankings for 2020 (Table 3), compared to World University Rankings for 2018 (Table 4), these data indicate that in the current year (2020) the following universities 
have improved their positions, namely: Stanford University (moved from the second place to the first), the University of Cambridge (moved from fifth place to the second), the University of Oxford (moved from sixth place to the fourth), the University of California, Berkeley (moved from the nineteenth place to the sixth), New York University (moved from the twelfth step to the ninth), Columbia University (moved from the seventeenth place to the sixteenth), the University of Hong Kong (moved from the eighteenth place to the seventeenth) (according to the ranking of the top 20 universities, defined by the World University Rankings).

Table 4. Ranking of the top 20 universities in the world according the level of teaching legal disciplines in 2018

\begin{tabular}{|c|c|c|c|c|c|}
\hline Country & Rank & University & $\begin{array}{l}\text { Number } \\
\text { of FTE } \\
\text { students }\end{array}$ & $\begin{array}{l}\text { Number of } \\
\text { students } \\
\text { per staff }\end{array}$ & $\begin{array}{l}\text { International } \\
\text { students, } \%\end{array}$ \\
\hline The United States & 1 & Duke University & 15256 & 4,5 & 22 \\
\hline The United States & 2 & Stanford University & 15845 & 7,5 & 22 \\
\hline The United States & 3 & Yale University & 12155 & 4,3 & 21 \\
\hline The United States & 4 & The University of Chicago & 13525 & 6,2 & 25 \\
\hline The United Kingdom & 5 & The University of Cambridge & 18389 & 10,9 & 35 \\
\hline The United Kingdom & 6 & The University of Oxford & 20409 & 11,2 & 38 \\
\hline Australia & 7 & The University of Melbourne & 42116 & 26,6 & 40 \\
\hline The United Kingdom & 8 & UCL & 30304 & 10,5 & 49 \\
\hline The United States & 9 & Harvard University & 20326 & 8,9 & 26 \\
\hline Canada & 10 & The University of Toronto & 69427 & 18,7 & 17 \\
\hline The United States & 11 & The University of Pennsylvania & 20361 & 6,5 & 20 \\
\hline The United States & 12 & New York University & 43860 & 9,6 & 26 \\
\hline Canada & 13 & McGill University & 30940 & 13,3 & 26 \\
\hline The United Kingdom & 14 & The University of Edinburgh & 26759 & 12,5 & 40 \\
\hline The United States & 15 & $\begin{array}{l}\text { The University of Michigan-Ann } \\
\text { Arbor }\end{array}$ & 41818 & 8,6 & 16 \\
\hline Canada & 16 & $\begin{array}{l}\text { The University of British } \\
\text { Columbia }\end{array}$ & 51889 & 18,1 & 29 \\
\hline The United States & 17 & Columbia University & 26587 & 6,1 & 32 \\
\hline Hong Kong & 18 & The University of Hong Kong & 18364 & 18,0 & 42 \\
\hline The United States & 19 & $\begin{array}{l}\text { The University of California, } \\
\text { Berkeley }\end{array}$ & 36182 & 13,1 & 17 \\
\hline The Netherlands & 20 & Leiden University & 24825 & 18,2 & 12 \\
\hline
\end{tabular}

Source: The World University Rankings (2019)

However, in 2020, thefollowing universities have worsened their positions, namely: the University of Chicago (moved from the fourth place to the fifth) and Duke University (moved from the first placeto the sixth), the University of Melbourne (moved from the seventh place to the twelfth), Harvard University (moved from the ninth place to the thirteenth), UCL (moved from the eighth place to the fourteenth), the University of Edinburgh (moved from the fourteenth place to the eighteenth), McGill University (moved from the thirteenth place to the twentieth) (according to the ranking of the top 20 universities, defined by the World University Rankings).

According to information, provided by the Study.com (2019) website, the key professional responsibilities of a modern Jurisprudence educator should include:

1) releavant and correct preparation for classes (lectures and practical studies), relying, at the same time, on the current legislative and regulatory framework;

2) promotion of active discussions of topical issues on jurisprudenceduring classes; 
3) respectable and appropriate assessment of students' learning outcomes;

4) direct and regular participation in various educational activities.

For instance, in the United States, according to the U. S. Bureau of Labor Statistics Latest Numbers (n.d.), a person with a master's degree in law, knowledge, skills and abilities in the field of law can apply for the position of the Jurisprudence educator at an educational institution. Herewith, in 2017, in the United States, the average salary of the Jurisprudence educator amounted only 104910 USD.

\section{Discussion}

Based on the conducted analysis and studyingthe theoretical and practical featuresof the professional competences' formation and development of Jurisprudence educators, it hasbeen established that modern law specialistshouldpossess the following professional competences, namely: perfect knowledge of modern law and otherlegal standards;to rely on the characteristics and qualities of leading scientists, working in this field; to be able to interconnect private and public interests and allocate responsibility to individual cases; to be well-versed in legislative practice and to act by law in unexpected situations; to encourage students to actively participate in the learning process, while avoiding delays in classes or even truancies; to expect knowledge from their students in a positive light; to treat students positively and with respect, regardless of their religious, cultural, social or linguistic background; to cooperate with parents and other students' custodial persons; to think critically and professionally; to prepare for classes to a full extent, using modern innovative teaching methods to teach material in the classroom; to take an active part in activities organized by the tertiary educational institution, local community, etc.; to be engaged in professional development, constantly improve one's own competences.

The study presents a number of leading institutions of tertiary education, one of the educational areas of which is the legal direction.According to the annual ranking of tertiary educational institutions, World University Rankings, presented by Times Higher Education magazine, it has been established that in 2020 the best universities in the world, occupying the first five positions among 190 universities in the world, and where highly professional Jurisprudence educators workare as follows: Stanford University (the United States), the University of Cambridge (the United Kingdom), Yale University (the United States), the University of Oxford (the United Kingdom) and the University of Chicago (the United States).

Studies prove that obtaining the career of the Jurisprudence educator at different institutions of tertiary education differs from each other. For instance, Stanford University (2014) has special programs that involve students in continuing research activities at this institution, on the basis of which students acquire appropriate knowledge and practical skills. In order to teach Jurisprudence at the University of Chicago (2020) (the United States), a potential educator should: 1) graduate with honors from law school, constantly provide their services regarding the review of the law, while holding a high editorial position; 2) complete studies with a high level of knowledge, possess practical skills and work experience in paperwork; 3) have additional academic experience, which is obtained by a potential educator during carrying out research activities after graduating from the law school. In order to conduct training at Yale Law School (n.d.) (the United States) a potential educator should possess: 1) academic literacy; 2) the availability of the necessary knowledge; 3) practical experience; 4) potential teaching ability, including the ability to hold classroom discussions or seminars; 5) a position in legal journals or holding a position in the legal service (optional). The process of teaching at Harvard Law School involves the participation of potential educators in programs that are specifically designed by Harvard Law School (n.d.) in order to attract only worthy teachers to the educational process. Prospective educators, who want to create a successful teaching career at Columbia Law School (the United States), should participate in programs specifically designed by Columbia Law School (2020), in particular, in the program "The Careers in Law Teaching", which is intended to provide graduates and students who are interested in further academic activities, assistance from professors in the development of an individual academic research program and preparation for building an educator's career in the future. A career of an educator at the University of Toronto, Faculty of Law, begins with obtaining of a bachelor's degree and passing a standardized LSAC test, the results of which are assessed by an independent non-profit organization. In order to coduct training at UC Berkeley School of Law (the United States), it is necessary to publish articles in legal journals, to have support from other educators concerning conducting training activities, as well as participate in the annual recruitment conference organized by the Association of American Law Schools (AALS). 


\section{Conclusion}

In the course of the study it has been established that a person with a master's degree in tertiary education, relevant knowledge, skills and abilities to work in the field of jurisprudence can apply for the position of the educator of Jurisprudence. Herewith, it should be noted that the prestige level of the tertiary educationalinstitution, wherethey carry out their professional activity, depends to some extent on the professional competences' level of educators of Jurisprudence.

Thus, based on the abovementioned results of the scientific research, it should be noted that the career growth of the educators of Jurisprudence to a large extent depends on their professional competences,forasmuch as the level of the educator's competence in the direction of its activities significantly affects the disclosure and implementation of his creative potential and teaching capacity.

In the course of the study it has been revealed that Jurisprudence educators should possess the following professional competences in the context of their professional activities, namely: positive and respectful attitude to students, regardless of their religious, cultural, social or linguistic origin; be guided by the law and ethical principles in the educational process; be polite to students in order to encourage them to learn; cooperate with parents and other caregivers of students; cooperate with other educators of the tertiary educational institution; take an active part in activities organized by the educational institution, local community, etc.; engage in their own professional development, constantly improve their competences.

\section{References}

Akhmejanova, G., Olzhabayev, B., Zhanara, K., Avikhan, A., \& Sakenov, J. (2016). Formation of professional competence of legal specialty students in the elective courses studying. International Journal of Environmental and Science Education, 11(18), 11163-11173.

Baklanova, N. M. (2016). Formation of legal competence of future teachers. Educological discourse, 2(14), $115-124$.

Berkeley School of Law. (n.d.). FAQ. https://www.law.berkeley.edu/careers/for-students/academic-careers/faq/

Cedefop. (2014). Terminology of European education and training policy: A selection of 130 key term. Retrieved from www.cedefop.europa.eu/en/publications-and-resources/publications/4117

Celik, S. (2011). Characteristics and competencies for teacher educators: Addressing the need for improved professional standards in Turkey. Australian Journal of Teacher Education, 36(4), 18-32. http://doi.org/10.14221/ajte.2011v36n4.3

Chakroun, B. (2019). National qualifications framework and TVET teacher competence frameworks: A neglected dimension of qualifications reforms? European Journal of Education: Research, Development and Policy, 54(3), 370-388. https://doi.org/10.1111/ejed.12359

Columbia Law School. (2020). Careers in Law Teaching. Retrieved from https://www.law.columbia.edu/careers/academic-careers/careers-law-teaching

DeLuca, Ch., Schneider, Ch., Coombs, A., Pozas, M., \& Rasooli, A. (2020). A cross-cultural comparison of German and Canadian student teachers' assessment competence. Journal Assessment in Education: Principles, Policy \& Practice, 27(1), 26-45. https://doi.org/10.1080/0969594X.2019.1703171

Education International. (2011). Quality educators: An international study of teacher competences and standards. Retrieved from https://policy-practice.oxfam.org.uk/publications/quality-educators-an-international-study-of-teacher-competenc es-and-standards-265732

European Commission. (2013). Supporting teacher competence development for better learning outcomes. Retrieved from https://ec.europa.eu/assets/eac/education/experts-groups/2011-2013/teacher/teachercomp_en.pdf

Fransson, G., Gallant, A., \& Shanks, R. (2018). Human elements and the pragmatic approach in the Australian, Scottish and Swedish standards for newly qualified teachers. Journal of Education Change, 19, 243-267. https://doi.org/10.1007/ s10833-018-9321-8

Gerst, S., \& Hess, G. (2009). Professional skills and values in legal education: The GPS model. Valparaiso University Law Review, 43(2), 513-557. 
Gherashhenko, V. V. (2018). Formation of a competently-oriented title of law in professional training conditions. Naukovi zapysky Nacionaljnogho pedaghoghichnogho universytetu imeni M. P. Draghomanova. Serija: Pedaghoghichni nauky: zbirnyk naukovykh statej, 139, 60-69.

Gherashhenko, V. V. (2019). Communicative competence as one of the components of the professional training of highly qualified law teachers. Innovative Pedagogy, 19(1), 65-68. https://doi.org/10.32843/2663-6085-2019-19-1-14

Harvard Law School. (n.d.). Law Teaching. Retrieved from https://hls.harvard.edu/dept/oaa/law-teaching/

Heath, M., Galloway, K., Skead, N., Steel, A., \& Israel, M. (2017). Learning to feel like a lawyer: Law teachers, sessional teaching and emotional labour in legal education. Griffith Law Review, 26(3), 430-457. https://doi.org/10.1080/10383441.2017.1406791

Hess, G. F. (2014). Qualitative research on legal education: Studying outstanding law teachers. Alberta Law Review, 51(4), 925-940. https://doi.org/10.29173/alr45

International Labour Office. (2019). Work for a brighter future - Global commission on the future of work. Retrieved from www.ilo.org/global/publications/books/WCMS_662410/lang-en/index.htm

Mottershead, T. \& Magliozzi, S. (2013). Can competencies drive change in the legal proffession. University of St. Thomas Law Journal, 11(1), 51-86.

Muslimov, N. A. \& Kadyrov, K. S. (2015). The development of professional competence of future professional teachers. Obrazovanie cherez vsju zhyznj: nepreryvnoe obrazovanie v interesakh ustojchivogho razvitija, 13, 348-349.

Prokopchuk, V. (2017). Methodical competence of a history and law teacher as a component of professional competence. Pedagogical Journal Volyn, 2(5), 95-102. https://doi.org/10.29038/2415-8143-2017-02-95-102

Schwartz, M. H., Hess, G. F. \& Sparrow, S. M. (2013). What the best law teachers do. Cambridge, MA: Harvard University Press.

Shestopaljuk, O. O. (2014). The structure of professional competence of future teachers of law. Adult Education: Theory, Experience, Prospects, 1(8), 145-153.

Siri, A., Supartha, I. W. G., Sukaatmadja, I. P. G., \& Rahyuda. A. G. (2020). Does teacher competence and commitment improve teacher's professionalism. Cogent Business \& Management, 7(1), 1-13. https://doi.org/10.1080/23311975.2020.1781993

Sparrow, S. M. (2018). Teaching and assessing soft skills. Journal of Legal Education, 67(2), 553-575. https://jle.aals.org/home/vol67/iss2/7/

Stanford University. (2014). Helping SLS Grads join the academy. StanfordLawSchool, 90. https://law.stanford.edu/areas_of_interest/academia/\#slsnav-helping-sls-grads-join-the-academy

Study.com. (2019). Law Teacher: Job Information \& Career Requirements. Retrieved from https://study.com/articles/Law_Teacher_Job_Information_and_Requirements_for_Becoming_a_Law_Teacher.h tml

The University of Chicago. (2020). Paths to law teaching. Retrieved from https://www.law.uchicago.edu/careerservices/pathstolawteaching

The World University Rankings. (2019). Best universities for law degrees 2020. Retrieved from https://www.timeshighereducation.com/student/best-universities/best-universities-law-degrees

Tsaoussi, A. I. (2020). Using soft skills courses to inspire law teachers: a new methodology for a more humanistic legal education. The Law Teacher, 54(1), 1-30. https://doi.org/10.1080/03069400.2018.1563396

U. S. Bureau of Labor Statistics Latest Numbers. (n.d). Retrieved from https://www.bls.gov/

United Nations. (2019). The age of interdependence. Retrieved from https://digitalcooperation.org/report/

University of Toronto Faculty of Law. (n.d). So, You Want to Become a Lawyer. Retrieved from https://www.law.utoronto.ca/admissions/youth-outreach/so-you-want-become-lawyer

Yale Law School. (n.d). Preparing for a career in law teaching. Retrieved from https://law.yale.edu/studying-law-yale/areas-interest/law-teaching/law-teaching-program/preparing-career-law-t eaching 